\title{
Procalcitonin Is a Specific Marker for Detecting Bacterial Infection in Patients with Rheumatoid Arthritis
}

\author{
HIROE SATO, NAOHITO TANABE, AKIRA MURASAWA, YASUHIRO OTAKI, TAKEHITO SAKAI, \\ TOSHIAKI SUGAYA, SATOSHI ITO, HIROSHI OTANI, ASAMI ABE, HAJIME ISHIKAWA, KIYOSHI NAKAZONO, \\ TAKESHI KURODA, MASAAKI NAKANO, and ICHIEI NARITA
}

\begin{abstract}
Objective. Rheumatoid arthritis (RA) is a chronic inflammatory disease accompanied by many complications, and serious infections are associated with many of the advanced therapeutics used to treat it. We assessed serum procalcitonin (PCT) levels to distinguish bacterial infection from other complications in patients with RA.

Methods. One hundred eighteen patients experiencing an RA flare, noninfectious complication of RA or its treatment, nonbacterial infection, or bacterial infection were studied. Serum PCT concentrations were determined with a chemiluminescent enzyme immunoassay.

Results. All patients experiencing an RA flare showed negative PCT levels $(\leq 0.1 \mathrm{ng} / \mathrm{ml} ; \mathrm{n}=18)$. The PCT level was higher in the bacterial infection group (25.8\% had levels $\geq 0.5 \mathrm{ng} / \mathrm{ml}$ ) than in the other 3 groups $(0.0-4.3 \%$ had levels $\geq 0.5 \mathrm{ng} / \mathrm{ml})$ and the difference was significant among groups $(\mathrm{p}=$ $0.003)$. Conversely, no statistically significant difference was observed among the groups with C-reactive protein $(\mathrm{CRP})$ concentration $\geq 0.3 \mathrm{mg} / \mathrm{dl}(\mathrm{p}=0.513)$, white blood cell (WBC) count $>8500 / \mathrm{mm}^{3}$ $(\mathrm{p}=0.053)$, or erythrocyte sedimentation rate $(\mathrm{ESR})>15 \mathrm{~mm} / \mathrm{h}(\mathrm{p}=0.328)$. The OR of high PCT level $(\geq 0.5 \mathrm{ng} / \mathrm{ml})$ for detection of bacterial infection was 19.13 (95\% CI 2.44-149.78, $\mathrm{p}=0.005$ ). Specificity and positive likelihood ratio of PCT $\geq 0.5 \mathrm{ng} / \mathrm{ml}$ were highest $(98.2 \%$ and 14.33 , respectively) for detection of bacterial infection, although the sensitivity was low (25.8\%).

Conclusion. Serum PCT level is a more specific marker for detection of bacterial infection than either CRP, ESR, or WBC count in patients with RA. High PCT levels ( $\geq 0.5 \mathrm{ng} / \mathrm{ml})$ strongly suggest bacterial infection. However, PCT $<0.5 \mathrm{ng} / \mathrm{ml}$, even if $<0.2 \mathrm{ng} / \mathrm{ml}$, does not rule out bacterial infection and physicians should treat appropriately. (First Release July 1 2012; J Rheumatol 2012;39:1517-23; doi:10.3899/jrheum.111601)
\end{abstract}

Key Indexing Terms:

PROCALCITONIN

BACTERIAL INFECTION
RHEUMATOID ARTHRITIS
C-REACTIVE PROTEIN
From the Department of Rheumatology, Niigata Rheumatic Center, Shibata City, Japan.

Supported by a grant from the Ministry of Health, Labor and Welfare, Research Committee for Early Diagnosis to Prevent Severe Complications of Rheumatoid Arthritis in Japan.

H. Sato, MD, PhD, Department of Rheumatology, Niigata Rheumatic Center; N. Tanabe, MD, PhD, Department of Health and Nutrition, Faculty of Human Life Studies, University of Niigata Prefecture, Niigata City; A. Murasawa, MD, PhD; Y. Otaki, MD, PhD; T. Sakai, MD, PhD; T. Sugaya, MD, PhD; S. Ito, MD, PhD; H. Otani, MD, PhD; A. Abe, MD, $P h D ; H$. Ishikawa, MD, PhD; K. Nakazono, MD, PhD, Department of Rheumatology, Niigata Rheumatic Center; T. Kuroda, MD, PhD;

I. Narita, MD, PhD, Division of Clinical Nephrology and Rheumatology, Niigata University Graduate School of Medical and Dental Sciences, Niigata City; M. Nakano, MD, PhD, Department of Medical Technology, School of Health Sciences, Faculty of Medicine, Niigata University, Niigata City.

Address correspondence to Dr. H. Sato, Department of Rheumatology, Niigata Rheumatic Center, 1-2-8 Honcho, Shibata City, Niigata, 957-0054, Japan.E-mail: hiroe-212@umin.ac.jp

Accepted for publication April 26, 2012.
Rheumatoid arthritis (RA) is an inflammatory disease that mainly affects synovial tissue. Several inflammatory cytokines, such as tumor necrosis factor (TNF), interleukin 1 (IL-1), and IL-6, are associated with RA, and cytokine blockade drugs have recently become an important treatment option $^{1,2}$. The prognosis of RA has improved considerably because of developments in drug therapy, but susceptibility to infections remains a major problem. Distinguishing infection from inflammation or other noninfectious complications is important in clinical practice. Identification of severe bacterial infections is a major concern because it influences whether antibiotics will be prescribed. For subjects with systemic inflammation caused by bacterial infections, immediate administration of antibiotics should be considered.

Procalcitonin (PCT) is a $13-\mathrm{kDa}$ precursor protein of calcitonin composed of 116 amino acids ${ }^{3}$. PCT is usually produced and cleaved to calcitonin in the $\mathrm{C}$ cells of the thyroid gland 
and is not detectable in normal control serum ${ }^{4}$. When bacterial infection accompanied by systemic inflammation occurs, PCT is produced in the liver, lung, kidney, adipocyte, and muscle, and levels in serum increase ${ }^{5}$. The cytokines IL-1ß and TNF then elevate levels of $\mathrm{PCT}^{5}$.

PCT levels in patients with arthritis are useful to discriminate bacterial arthritis and noninfectious arthritis such as RA, reactive arthritis, and crystal arthritis ${ }^{6,7,8}$. However, the efficacy of using PCT levels to identify bacterial complications in patients with RA has not been well investigated. Our study clarified whether serum PCT levels on admission can predict the final diagnosis of bacterial infection assessed using all clinical findings by physicians who were blind to the PCT levels in patients with RA.

\section{MATERIALS AND METHODS}

Subjects. The study subjects were 118 consecutive patients with RA admitted to the Niigata Rheumatic Centre between February 2008 and March 2009 because of either RA flare or infectious/noninfectious complications. Patients were excluded if they had RA without complications or flares. The study patients were divided into 4 groups: those with RA flare, noninfectious complication of RA or its treatment, RA with nonbacterial infection, or RA with bacterial infection. Bacterial infections included general bacterial and mycobacterium infections. Nonbacterial infections were viral or fungal infections including pneumocystis pneumonia. The "gold standard" for diagnosis of bacterial infection was final diagnosis based on the symptoms, bacterial culture tests, imaging studies, and response to antibiotic therapy. Because bacterial cultures are not always positive in all bacterial infections and false positives (colonization) can occur, physicians should comprehensively make the final diagnosis using all clinical findings. Our study aimed to reveal that PCT levels at admission can predict the final diagnosis of bacterial infection. Thus the final diagnosis in this study took into consideration all clinical features observed throughout hospitalization, by physicians who were blind to the PCT levels. All blood samples and cultures were obtained before antibiotic therapy was initiated and blood samples were stored at $-80^{\circ} \mathrm{C}$. The serum PCT concentration was measured after the final diagnosis had been made by each physician. Each patient met the 1987 American Rheumatism Association criteria for $\mathrm{RA}^{9}$. Anatomical stage and functional class were determined using the system proposed by Steinbrocker, et $a l^{10}$.

The study protocol was approved by the ethics committee of Niigata Rheumatic Centre and executed according to the Declaration of Helsinki. Written informed consent was obtained from all participants.

Biochemical assays of PCT. The PCT concentration was determined using serum samples collected before antibiotic therapy and stored at $-80^{\circ} \mathrm{C}$ by a chemiluminescent enzyme immunoassay (CLEIA; SphereLight PCT ${ }^{\circledR}$; Wako Pure Chemical Industries, Osaka, Japan). For the study, 2 cutoff values were determined to identify bacterial infections, $\geq 0.2 \mathrm{ng} / \mathrm{ml}$ and $\geq 0.5 \mathrm{ng} / \mathrm{ml}$, because the minimum value was $\leq 0.1 \mathrm{ng} / \mathrm{ml}$ and $0.2 \mathrm{ng} / \mathrm{ml}$ was the first positive value of PCT, and the recommended cutoff value for bacterial sepsis was $\geq 0.5 \mathrm{ng} / \mathrm{ml}^{11}$.

Other inflammatory markers. We used C-reactive protein (CRP), erythrocyte sedimentation rate (ESR), and white blood cell (WBC) count as inflammatory markers. Cutoff criteria were determined as $\geq 0.3 \mathrm{mg} / \mathrm{dl}$ for CRP, $>15$ $\mathrm{mm} / \mathrm{h}$ for ESR, and $>8500 / \mathrm{mm}^{3}$ for WBC count, which are the values considered abnormal at our clinic.

Statistical analysis. To compare baseline characteristics among the 4 groups - RA flare, noninfectious complication of RA or its treatment, RA with nonbacterial infection, and RA with bacterial infection - 1-way analysis of variance was used for continuous variables and chi-square test was applied for categorical variables. Distributions of inflammatory markers were described using the median and interquartile range, and the difference between groups was assessed by the Kruskal-Wallis test. Prevalence of abnormal inflammatory markers was compared using a chi-square test. For prevalence, 95\% CI were calculated based on binominal distribution. To assess the strength of association between abnormal values of inflammatory markers and bacterial infection, OR and CI were calculated using unadjusted logistic regression analysis. The screening potential of these cutoff criteria for bacterial infection was compared using sensitivity, specificity, positive and negative predictive values, and positive and negative likelihood ratios. Statistical analyses were performed with SPSS v19 (SPSS Inc., Chicago, IL, USA). The 95\% CI for prevalence were calculated using Microsoft Excel 2007 (Microsoft Inc., Redmond, WA, USA). $\mathrm{P}<0.05$ was considered statistically significant.

\section{RESULTS}

Characteristics of study subjects. The characteristics of subjects are listed in Table 1. Age, sex, body temperature, hemoglobin level, platelet count, and use of drugs for RA were not significantly different among the 4 study groups.

Distribution of inflammatory markers and positive prevalence. Distributions of PCT levels and WBC counts were significantly different among the 4 study groups and the median value was higher in the bacterial infection group than the other 3 groups. However, median values of CRP or ESR were not (Table 2). No patient with RA flare showed PCT $\geq 0.2 \mathrm{ng} / \mathrm{ml}$ and only 1 patient with noninfectious complications showed PCT $\geq 0.5 \mathrm{ng} / \mathrm{ml}$. Using standard cutoff criteria, the prevalence of PCT $\geq 0.5$ and $\geq 0.2 \mathrm{ng} / \mathrm{ml}$ was significantly different between groups ( $\mathrm{p}=0.003, \mathrm{p}=0.013$, respectively) and was most frequent in the bacterial infection group. However, the prevalence of abnormal CRP, WBC count, and ESR was not significantly different $(\mathrm{p}=0.513, \mathrm{p}=0.053, \mathrm{p}=0.328$, respectively; Table 2).

Diagnosis of complications in patients with RA. Table 3 compares diagnosis of complications and PCT levels. Among patients with RA who had complications other than bacterial infection, only 1, with exacerbation of interstitial pneumonia associated with RA (RA lung), showed PCT $\geq 0.5 \mathrm{ng} / \mathrm{ml}$ (0.7 $\mathrm{ng} / \mathrm{ml})$. Slightly elevated PCT levels $(\geq 0.2 \mathrm{ng} / \mathrm{ml}$ ) were observed in all of 3 patients with secondary amyloidosis associated with RA $(0.2,0.2$, and $0.3 \mathrm{ng} / \mathrm{ml}$, respectively), and in those with meningitis due to Cryptococcus and panperitonitis due to Candida albicans $(0.2$ and $0.3 \mathrm{ng} / \mathrm{ml}$, respectively). Although the prevalence of elevated PCT was high in RA complicated by bacterial infection, some patients with general bacterial pneumonia (21/27), urinary tract infections (3/7), acute bronchitis (2/3), infectious colitis (3/4), infectious arthritis (1/2), and wound infection (3/4), and all with cellulitis $(6 / 6)$ and nontuberculous mycobacterial pneumonia $(2 / 2)$ did not satisfy even the low threshold of elevated PCT $(\geq 0.2$ $\mathrm{ng} / \mathrm{ml})$.

Of 62 patients with bacterial infection, 22 had positive cultures. Of the remaining 40 patients, 27 cases were diagnosed based on typical image findings (patients with pneumonia, acute necrotizing pancreatitis, or acute cholangitis, and some patients with wound infections), and the other 13 patients were diagnosed based on clinical manifestations and response 
Table 1. Characteristics of the study subjects. Data are mean $\pm \mathrm{SD}$ or number (\%).

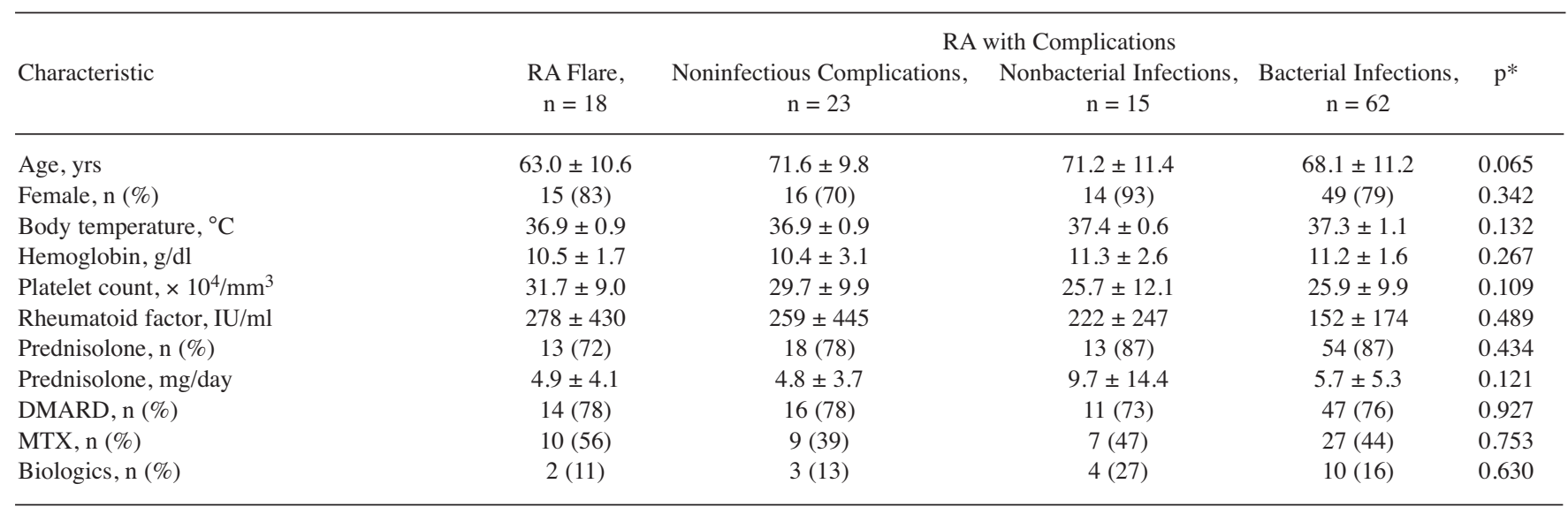

* 1-way analysis of variance or chi-square test. RA: rheumatoid arthritis; DMARD: disease-modifying antirheumatic drugs; MTX: methotrexate.

Table 2. Distribution of inflammatory markers and positive prevalence.

\begin{tabular}{|c|c|c|c|c|c|}
\hline$\geq 0.2 \mathrm{ng} / \mathrm{ml}, \mathrm{n}\left(\%\left[95 \% \mathrm{CI}^{*}\right]\right)$ & $0(0.0[0.0-18.5])$ & $4(17.4[5.0-38.8])$ & $2(13.3[1.7-40.5])$ & $21(33.9$ [22.3-47.0]) & 0.013 \\
\hline$\geq 0.5 \mathrm{ng} / \mathrm{ml}, \mathrm{n}\left(\%\left[95 \% \mathrm{CI}^{*}\right]\right)$ & $0(0.0[0.0-18.5])$ & $1(4.3[0.1-21.9])$ & $0(0.0[0.0-21.8])$ & $16(25.8[15.5-38.5])$ & 0.003 \\
\hline CRP, mg/dl, median (IQR) & $4.4(2.75,10.00)$ & $5.7(2.80,9.90)$ & $8.7(1.85,11.90)$ & $9.4(4.45,14.90)$ & 0.084 \\
\hline$>8500 / \mathrm{mm}^{3}, \mathrm{n}\left(\%\left[95 \% \mathrm{CI}^{*}\right]\right)$ & $7(38.9[17.3-64.3])$ & $9(39.1[19.7-61.5])$ & $7(46.7$ [21.3-73.4]) & $41(66.1$ [53.0-77.7]) & 0.053 \\
\hline ESR, mm/h, median (IQR) & $70(61,97.5)$ & $83(50,96)$ & $67(35,90.5)$ & $57(40,86)$ & 0.296 \\
\hline$\geq 15 \mathrm{~mm} / \mathrm{h} \mathrm{n}(\%[95 \% \mathrm{CI} *])$ & $15(83.3[58.6-96.4])$ & $18(78.3[56.3-92.5])$ & $8(53.3[26.6-78.7])$ & $53(85.5[74.2-93.1])$ & 0.328 \\
\hline
\end{tabular}

* Binomial distribution. ${ }^{\dagger}$ Kruskal-Wallis test for distribution of inflammatory markers and chi-square test for prevalence. IQR: interquartile range; PCT: serum procalcitonin; CRP: C-reactive protein; WBC: white blood cell count; ESR: erythrocyte sedimentation rate; RA: rheumatoid arthritis.

to antibiotic therapy (patients with cellulitis or febrile neutropenia, some patients with infectious colitis or urinary tract infection, etc.). Only 7 (31.8\%) of the 22 patients with positive cultures had PCT $\geq 0.5 \mathrm{ng} / \mathrm{ml}$ (none showed PCT level between 0.2 and $0.5 \mathrm{ng} / \mathrm{ml}$ ), and 2 of those had a positive result on blood culture; 1 was urinary tract infection with Mycoplasma hominis (PCT $1.3 \mathrm{ng} / \mathrm{ml}$ ) and the other was infectious aneurysm with Staphylococcus aureus (PCT 1.8 $\mathrm{ng} / \mathrm{ml}$ ). No significant correlation was observed between PCT and CRP levels in patients with bacterial infection whose PCT levels were $\geq 0.2 \mathrm{ng} / \mathrm{ml}$ (Spearman's rho $=0.204, \mathrm{p}=0.375$; $\mathrm{n}=21)$.

Among patients with bacterial infections, 10 used biologics (TNF inhibitor in 7 patients and anti-IL-6 receptor antagonist in 3). Positive rates of PCT ( $\geq 0.2$ and $\geq 0.5 \mathrm{ng} / \mathrm{ml}$ ) did not differ between patients using biologic therapies and all patients with bacterial infections [4/10 (40.0\%) vs $17 / 52$ $(32.7 \%)$ and $2 / 10(20.0 \%)$ vs $14 / 52(26.9 \%)$, respectively]. For patients treated with IL-6 receptor antagonist, the positive rate of PCT $(\geq 0.2$ and $\geq 0.5 \mathrm{ng} / \mathrm{ml}$ ) was not low $-2 / 3$ $(60.0 \%)$ and $1 / 3(33.3 \%)$, respectively.
Screening potential for detecting bacterial infections. The screening potential of abnormal inflammatory markers for identifying bacterial infections among patients with RA was assessed (Table 4). PCT levels $\geq 0.2$ and $\geq 0.5 \mathrm{ng} / \mathrm{ml}$ were significantly associated with bacterial infection, and the OR for PCT $\geq 0.5 \mathrm{ng} / \mathrm{ml}$ was very high (OR 19.13, 95\% CI 2.44-149.78). Using PCT $\geq 0.5 \mathrm{ng} / \mathrm{ml}$, although the sensitivity was low $(25.8 \%)$, the specificity $(98.2 \%)$, positive predictive value (94.1), and positive likelihood ratio (14.33) were higher than those of other abnormal inflammatory markers: only 1 of 17 patients (5.9\%) who had RA without bacterial infection showed a false-positive. The sensitivity remained low (33.9\%) even when the lower value, $\geq 0.2 \mathrm{ng} / \mathrm{ml}$, was used as the positive determinant of elevated PCT. WBC count $>8500 / \mathrm{mm}^{3}$ was also significantly associated with bacterial infection (OR 2.80, 95\% CI 1.33-5.92). However, WBC count $>8500 / \mathrm{mm}^{3}$ did not identify 3 of 16 patients with bacterial infection having PCT $\geq 0.5 \mathrm{ng} / \mathrm{ml}$. Further, WBC count $>8500 / \mathrm{mm}^{3}$ was more frequently observed in cases of RA flare, complications due to RA or RA treatment, and nonbacterial infections than was PCT $\geq 0.5 \mathrm{ng} / \mathrm{ml}$. Thus, the speci- 
Table 3. Diagnosis of complications in patients with rheumatoid arthritis (RA).

\begin{tabular}{|c|c|c|c|}
\hline Condition & $\mathrm{N}$ & $\begin{array}{c}\mathrm{PCT} \geq 0.5 \mathrm{ng} / \mathrm{ml} \\
\mathrm{n}(\%)\end{array}$ & $\begin{array}{c}\mathrm{PCT} \geq 0.2 \mathrm{ng} / \mathrm{ml}, \\
\mathrm{n}(\%)\end{array}$ \\
\hline \multicolumn{4}{|l|}{ RA patients with noninfectious complications } \\
\hline RA lung & 9 & $1(11)$ & $1(11)$ \\
\hline Methotrexate pneumonia & 5 & $0(0)$ & $0(0)$ \\
\hline RA amyloidosis & 3 & $0(0)$ & $3(100)$ \\
\hline Malignancy & 2 & $0(0)$ & $0(0)$ \\
\hline Eosinophilic pneumonia & 1 & $0(0)$ & $0(0)$ \\
\hline Fracture & 1 & $0(0)$ & $0(0)$ \\
\hline Pseudogout & 1 & $0(0)$ & $0(0)$ \\
\hline Drug eruption due to sulfasalazine & 1 & $0(0)$ & $0(0)$ \\
\hline \multicolumn{4}{|l|}{ RA patients with nonbacterial infections } \\
\hline Acute bronchitis & 4 & $0(0)$ & $0(0)$ \\
\hline Pneumocystis jirovecii pneumonia & 4 & $0(0)$ & $0(0)$ \\
\hline Herpes zoster & 2 & $0(0)$ & $0(0)$ \\
\hline Meningitis (Cryptococcus) & 2 & $0(0)$ & $1(50)$ \\
\hline Panperitonitis (Candida) & 1 & $0(0)$ & $1(100)$ \\
\hline Pneumonia (Aspergillus) & 1 & $0(0)$ & $0(0)$ \\
\hline Pulmonary abscess (Aspergillus) & 1 & $0(0)$ & $0(0)$ \\
\hline \multicolumn{4}{|l|}{ Patients with RA having bacterial infections } \\
\hline Pneumonia (general bacteria) & 27 & $3(11)$ & $6(22)$ \\
\hline Urinary tract infection & 7 & $3(43)$ & $4(57)$ \\
\hline Cellulitis & 6 & $0(0)$ & $0(0)$ \\
\hline Infectious colitis (not due to Clostridium difficile) & 4 & $1(25)$ & $1(25)$ \\
\hline Wound infection & 4 & $0(0)$ & $1(25)$ \\
\hline $\begin{array}{l}\text { Acute bronchitis with bronchial ectasia } \\
\text { (S. pneumoniae or P. auruginosa) }\end{array}$ & 3 & $1(33)$ & $1(33)$ \\
\hline Infectious arthritis & 2 & $1(50)$ & $1(50)$ \\
\hline Pneumonia (nontuberculous mycobacteria) & 2 & $0(0)$ & $0(0)$ \\
\hline Cholecystitis & 1 & $1(100)$ & $1(100)$ \\
\hline Acute cholangitis & 1 & $1(100)$ & $1(100)$ \\
\hline Acute necrotizing pancreatitis & 1 & $1(100)$ & $1(100)$ \\
\hline Febrile neutropenia & 1 & $1(100)$ & $1(100)$ \\
\hline Infectious endocarditis & 1 & $1(100)$ & $1(100)$ \\
\hline Infectious aneurysm (S. aureus) & 1 & $1(100)$ & $1(100)$ \\
\hline Pneumonia (tuberculosis) & 1 & $1(100)$ & $1(100)$ \\
\hline
\end{tabular}

Table 4. The screening potential of serum procalcitonin, C-reactive protein, white blood cell count, and erythrocyte sedimentation rate for detecting bacterial infections and strictly bacterial infections in patients with rheumatoid arthritis. Bacterial infection was finally diagnosed based on symptoms, bacterial culture tests, imaging studies, and response to antibiotic therapy. Strictly bacterial infection was diagnosed based on bacterial culture tests and/or imaging studies. OR, 95\% CI, and p values were calculated by nonadjusted logistic regression analysis.

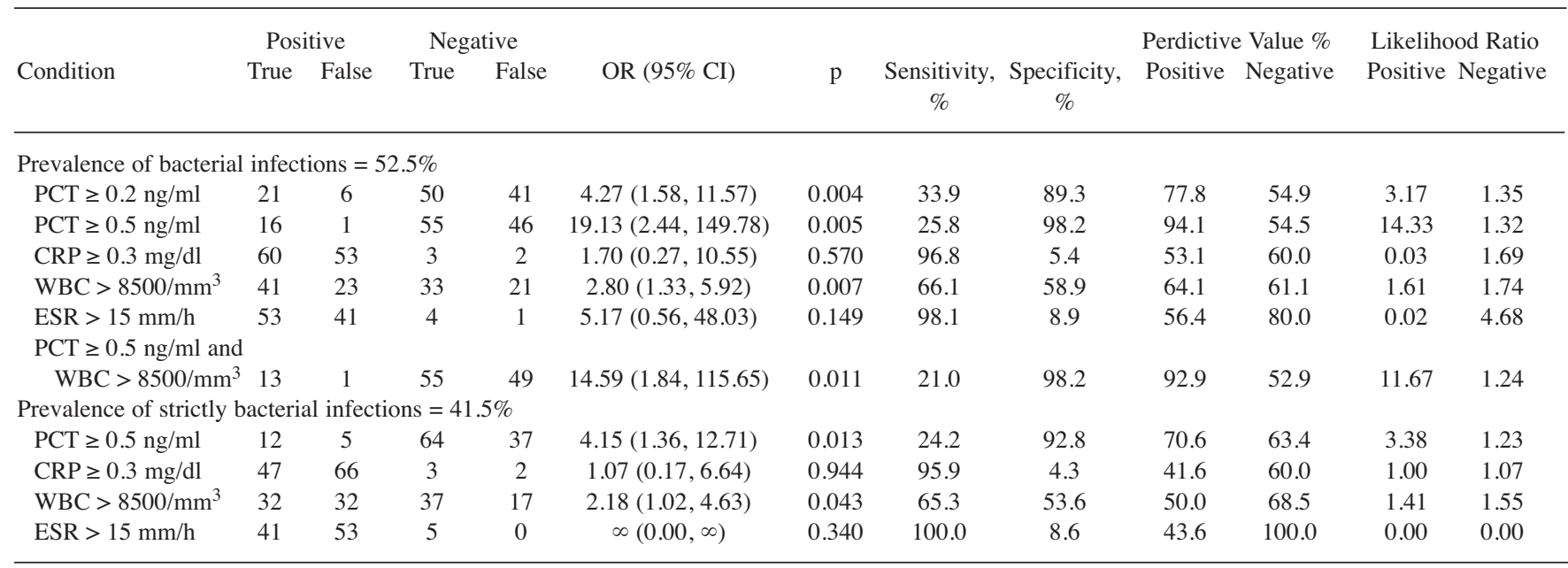

PCT: serum procalcitonin; CRP: C-reactive protein; WBC: white blood cell count; ESR: erythrocyte sedimentation rate. 
ficity and positive likelihood ratio of the WBC count $>$ $8500 / \mathrm{mm}^{3}$ (58.9\% and 1.61, respectively) were far lower than those of the PCT $\geq 0.5 \mathrm{ng} / \mathrm{ml}$, showing that PCT $\geq 0.5 \mathrm{ng} / \mathrm{ml}$ is a much more specific marker of bacterial infection than WBC count $>8500 / \mathrm{mm}^{3}$. Also, combining PCT $\geq 0.5 \mathrm{ng} / \mathrm{ml}$ and WBC count $>8500 / \mathrm{mm}^{3}$ did not improve any screening indices for bacterial infection compared with using only PCT $\geq 0.5 \mathrm{ng} / \mathrm{ml}$.

When bacterial infection was defined strictly as diagnosed by positive cultures and/or typical image findings $(n=49$, $41.5 \%$ ), PCT level $\geq 0.5 \mathrm{ng} / \mathrm{ml}$ and $\mathrm{WBC}$ count $>8500 / \mathrm{mm}^{3}$ were significantly associated with strictly bacterial infection (OR 4.15, 95\% CI 1.36-12.71, p = 0.013, and OR 2.18, 95\% CI $1.02-4.63, \mathrm{p}=0.043$, respectively). Five patients with PCT $\geq 0.5 \mathrm{ng} / \mathrm{ml}$ were false-positive and a positive likelihood ratio of PCT $\geq 0.5 \mathrm{ng} / \mathrm{ml}$ decreased lower (3.38) than that for detection of bacterial infection (14.33); however, PCT $\geq 0.5 \mathrm{ng} / \mathrm{ml}$ had the highest OR, specificity, and positive likelihood ratio, compared with other inflammation markers (Table 4).

\section{DISCUSSION}

The results of our study indicate clearly that the serum PCT level is a more specific marker for detection of bacterial infection than other inflammatory markers, such as CRP, ESR, or WBC count, in patients with RA. PCT level $\geq 0.5 \mathrm{ng} / \mathrm{ml}$ showed a very high OR for detection of bacterial infection and also showed few false positives. Thus, PCT $\geq 0.5 \mathrm{ng} / \mathrm{ml}$ strongly suggests the presence of bacterial infections and indicates requirement for immediate antibiotic therapy.

PCT has been described as a marker of systemic infection such as sepsis and septic shock ${ }^{11,12}$. In our study, elevated PCT was observed in patients with cholecystitis, acute cholangitis, acute necrotizing pancreatitis, febrile neutropenia, infectious endocarditis, or infectious aneurysm. These severe bacterial infections should be immediately treated with antibiotics, thus measurement of PCT levels is meaningful in patients with RA who have signs suggesting infectious complications.

No patient with RA flare in our study showed elevated PCT levels, similar to previous reports ${ }^{6,7,8}$. Several studies have reported elevated PCT without infection in patients with autoimmune diseases $13,14,15,16,17,18,19,20,21$ such as adult-onset Still's disease ${ }^{18}$, granulomatosis with polyangiitis (Wegener granulomatosis) ${ }^{15,20}$, and Goodpasture syndrome ${ }^{16}$. These autoimmune diseases often cause a sepsis-like high fever. Massive production of inflammatory cytokines such as TNF and IL-6 in such sepsis-like conditions ${ }^{22,23,24,25,26}$ may stimulate the production of PCT. Although elevation of these serum cytokines has also been reported in patients with $\mathrm{RA}^{27,28}$, this may be unusual because sepsis-like high fever is rare in chronic inflammatory diseases such as RA. In our study, PCT remained elevated despite treatment with biologics. However, as the number of patients using biologics was small and the types of bacterial infections differed, further study is needed to investigate the possible effects of biologics on PCT.
Christ-Crain, et al have proposed PCT-guided use of antibiotic agents in patients with lower respiratory tract infections ${ }^{29}$. According to their stratification criteria, antibiotic therapies are discouraged when PCT levels are $<0.25 \mathrm{ng} / \mathrm{ml}$. Using this therapeutic guideline, they were able to reduce use of antibiotics without worsening prognosis. However, their guidelines should not be applied to patients with RA. In our study, many cases of bacterial infection were found even when serum PCT levels were $<0.2 \mathrm{ng} / \mathrm{ml}$. Regarding general bacterial pneumonia, 21 of 27 cases had serum PCT levels < $0.2 \mathrm{ng} / \mathrm{ml}$. Normal PCT levels have frequently been observed in patients with RA who had bacterial infections ${ }^{19}$. Further, our findings together with some previous reports ${ }^{19,30}$ suggest that PCT levels are not elevated in patients with local infections, such as wound infection or cellulitis. Because patients with RA are usually immunocompromised as a result of their RA treatment, immediate treatment of bacterial infection is of critical importance. Therefore, low serum PCT levels should not prevent the use of antibiotic therapy when signs of bacterial infection are present.

In our study, WBC counts $>8500 / \mathrm{mm}^{3}$ were also significantly associated with bacterial infection. This association was less specific than PCT $\geq 0.2 \mathrm{ng} / \mathrm{ml}$. Therefore, bacterial infections should be carefully considered in patients with WBC $>8500 / \mathrm{mm}^{3}$ despite a normal PCT finding. However, antibiotic therapy should be initiated in any patient with PCT $\geq 0.5 \mathrm{ng} / \mathrm{ml}$ with normal WBC, because the WBC count is not always $>8500 / \mathrm{mm}^{3}$ in bacterial infection.

We note that patients with RA amyloidosis showed slightly elevated PCT levels $(0.2$ to $<0.5 \mathrm{ng} / \mathrm{ml})$. All had severe diarrhea due to secondary amyloidosis associated with RA. In such patients, latent infection through the damaged intestinal mucosa might be present ${ }^{31}$. Amyloidosis itself also causes severe inflammation ${ }^{32}$. When these infectious and noninfectious inflammations exist simultaneously, production of PCT may result. Thus, the slightly elevated PCT in patients with RA with diarrhea might be useful as a marker of secondary amyloidosis associated with RA. Larger studies are needed to elucidate this hypothesis.

We used the CLEIA method to determine PCT levels, which is a quantitative analysis. Recently, a semiquantitative method for PCT has been developed. Since semiquantitative methods require neither specialized instrumentation nor techniques, use of this method has become commonplace. However, rheumatoid factor and human anti-mouse antibodies can affect the results of this semiquantitative method ${ }^{33,34}$; thus we selected a quantitative method for our study. A semiquantitative method for PCT should be interpreted carefully, especially in patients with RA.

The gold standard for bacterial infection in our study was a clinical diagnosis based on symptoms, bacterial cultures, image studies, and response to antibiotic therapy by physicians blind to the PCT levels. Theoretically, the gold standard should have been positive culture testing, but in this study,

Personal non-commercial use only. The Journal of Rheumatology Copyright @ 2012 . All rights reserved. 
only 22/62 patients with bacterial infection had a positive culture result; this is a major limitation of our study. However, not all bacterial species can be detected on cultures, and the results should be interpreted carefully because of the possibility for false positives. Further, when diagnosis of bacterial infection was defined strictly by positive cultures and/or typical image findings, PCT $\geq 0.5 \mathrm{ng} / \mathrm{ml}$ was most significantly associated with bacterial infection, as compared to other inflammatory markers. The main purpose of our study was to minimize the interval from admission of patients with complicated RA to confirmation of the diagnosis of bacterial infection in order to start appropriate antibiotic therapy as early as possible. For this purpose, our gold standard would be reasonable.

Another limitation is that patients with various complications were included in order to determine that elevated PCT is rare in nonbacterial complications. Because study subjects must be chosen at random, we included consecutive patients admitted as a result of complicated RA. Consequently, patients with localized bacterial infections were recruited, although they were not expected to have elevated PCT levels. Nevertheless, elevated PCT was observed to be strongly associated with bacterial infection. Further studies are needed to clarify whether PCT can differentiate bacterial infections in specific situations: for example, for differential diagnosis of bacterial pneumonia, nonbacterial infectious pneumonia, RA lung, and drug-induced pneumonia.

A serum PCT level $\geq 0.5 \mathrm{ng} / \mathrm{ml}$ strongly suggests the presence of bacterial infections in patients hospitalized because of complicated RA, and immediate antibiotic therapy is recommended for such patients showing any signs of infection. However, physicians should be aware that a PCT finding $<0.2$ $\mathrm{ng} / \mathrm{ml}$ does not rule out the presence of bacterial infection.

\section{REFERENCES}

1. Smolen JS, Aletaha D, Koeller M, Weisman MH, Emery P. New therapies for treatment of rheumatoid arthritis. Lancet 2007;370:1861-74.

2. Smolen JS, Landewe R, Breedveld FC, Dougados M, Emery P, Gaujoux-Viala C, et al. EULAR recommendations for the management of rheumatoid arthritis with synthetic and biological disease-modifying antirheumatic drugs. Ann Rheum Dis 2010;69:964-75.

3. Oberhoffer M, Karzai W, Meier-Hellmann A, Reinhart K. Procalcitonin. A new diagnostic parameter for severe infections and sepsis. Anaesthesist 1998;47:581-7.

4. Becker KL, Nylen ES, White JC, Muller B, Snider RH Jr. Clinical review 167: Procalcitonin and the calcitonin gene family of peptides in inflammation, infection, and sepsis: A journey from calcitonin back to its precursors. J Clin Endocrinol Metab 2004;89:1512-25.

5. Linscheid P, Seboek D, Nylen ES, Langer I, Schlatter M, Becker $\mathrm{KL}$, et al. In vitro and in vivo calcitonin I gene expression in parenchymal cells: a novel product of human adipose tissue. Endocrinology 2003;144:5578-84.

6. Hugle T, Schuetz P, Mueller B, Laifer G, Tyndall A, Regenass S, et al. Serum procalcitonin for discrimination between septic and non-septic arthritis. Clin Exp Rheumatol 2008;26:453-6.
7. Kuuliala A, Takala A, Siitonen S, Leirisalo-Repo M, Repo H. Cellular and humoral markers of systemic inflammation in acute reactive arthritis and early rheumatoid arthritis. Scand J Rheumatol 2004;33:13-8.

8. Martinot M, Sordet C, Soubrier M, Puechal X, Saraux A, Liote F, et al. Diagnostic value of serum and synovial procalcitonin in acute arthritis: A prospective study of 42 patients. Clin Exp Rheumatol 2005;23:303-10.

9. Arnett FC, Edworthy SM, Bloch DA, McShane DJ, Fries JF, Cooper NS, et al. The American Rheumatism Association 1987 revised criteria for the classification of rheumatoid arthritis. Arthritis Rheum 1988;31:315-24.

10. Steinbrocker $\mathrm{O}$, Traeger $\mathrm{CH}$, Batterman RC. Therapeutic criteria in rheumatoid arthritis. J Am Med Assoc 1949;140:659-62.

11. Aikawa N, Fujishima S, Endo S, Sekine I, Kogawa K, Yamamoto $\mathrm{Y}$, et al. Multicenter prospective study of procalcitonin as an indicator of sepsis. J Infect Chemother 2005;11:152-9.

12. Nylen ES, Whang KT, Snider RH Jr, Steinwald PM, White JC, Becker KL. Mortality is increased by procalcitonin and decreased by an antiserum reactive to procalcitonin in experimental sepsis. Crit Care Med 1998;26:1001-6.

13. Delevaux I, Andre M, Colombier M, Albuisson E, Meylheuc F, Beque RJ, et al. Can procalcitonin measurement help in differentiating between bacterial infection and other kinds of inflammatory processes? Ann Rheum Dis 2003;62:337-40.

14. Eberhard OK, Haubitz M, Brunkhorst FM, Kliem V, Koch KM, Brunkhorst R. Usefulness of procalcitonin for differentiation between activity of systemic autoimmune disease (systemic lupus erythematosus/systemic antineutrophil cytoplasmic antibody-associated vasculitis) and invasive bacterial infection. Arthritis Rheum 1997;40:1250-6.

15. Moosig F, Csernok E, Reinhold-Keller E, Schmitt W, Gross WL. Elevated procalcitonin levels in active Wegener's granulomatosis. J Rheumatol 1998;25:1531-3.

16. Morath C, Sis J, Haensch GM, Zeier M, Andrassy K, Schwenger V. Procalcitonin as marker of infection in patients with Goodpasture's syndrome is misleading. Nephrol Dial Transplant 2007;22:2701-4.

17. Quintana G, Medina YF, Rojas C, Fernandez A, Restrepo JF, Rondon F, et al. The use of procalcitonin determinations in evaluation of systemic lupus erythematosus. J Clin Rheumatol 2008; $14: 138-42$.

18. Scire CA, Cavagna L, Perotti C, Bruschi E, Caporali R, Montecucco C. Diagnostic value of procalcitonin measurement in febrile patients with systemic autoimmune diseases. Clin Exp Rheumatol 2006;24:123-8.

19. Tamaki K, Kogata Y, Sugiyama D, Nakazawa T, Hatachi S, Kageyama G, et al. Diagnostic accuracy of serum procalcitonin concentrations for detecting systemic bacterial infection in patients with systemic autoimmune diseases. J Rheumatol 2008;35:114-9.

20. Zycinska K, Wardyn KA, Zielonka TM, Tyszko P, Straburzynski M. Procalcitonin as an indicator of systemic response to infection in active pulmonary Wegener's granulomacytosis. J Physiol Pharmacol 2008;59 Suppl 6:839-44.

21. Buhaescu I, Yood RA, Izzedine H. Serum procalcitonin in systemic autoimmune diseases - where are we now? Semin Arthritis Rheum 2010;40:176-83.

22. Chen DY, Lan JL, Lin FJ, Hsieh TY. Proinflammatory cytokine profiles in sera and pathological tissues of patients with active untreated adult onset Still's disease. J Rheumatol 2004;31:2189-98.

23. Kadar J, Petrovicz E. Adult-onset Still's disease. Best Pract Res Clin Rheumatol 2004;18:663-76.

24. Lamprecht P, Kumanovics G, Mueller A, Csernok E, Komocsi A, Trabandt A, et al. Elevated monocytic IL-12 and TNF-alpha production in Wegener's granulomatosis is normalized by cyclophosphamide and corticosteroid therapy. Clin Exp Immunol 
2002;128:181-6.

25. Ito Y, Fukatsu A, Baba M, Mizuno M, Ichida S, Sado Y, et al. Pathogenic significance of interleukin-6 in a patient with antiglomerular basement membrane antibody-induced glomerulonephritis with multinucleated giant cells. Am J Kidney Dis 1995;26:72-9.

26. Rau M, Schiller M, Krienke S, Heyder P, Lorenz H, Blank N. Clinical manifestations but not cytokine profiles differentiate adult-onset Still's disease and sepsis. J Rheumatol 2010;37:2369-76.

27. Takeuchi T, Miyasaka N, Tatsuki Y, Yano T, Yoshinari T, Abe T, et al. Baseline tumour necrosis factor alpha levels predict the necessity for dose escalation of infliximab therapy in patients with rheumatoid arthritis. Ann Rheum Dis 2011;70:1208-15.

28. Knudsen LS, Hetland ML, Johansen JS, Skjodt H, Peters ND, Colic A, et al. Changes in plasma IL-6, plasma VEGF and serum YKL-40 during treatment with etanercept and methotrexate or etanercept alone in patients with active rheumatoid arthritis despite methotrexate therapy. Biomark Insights 2009;4:91-5.

29. Christ-Crain M, Jaccard-Stolz D, Bingisser R, Gencay MM, Huber PR, Tamm M, et al. Effect of procalcitonin-guided treatment on antibiotic use and outcome in lower respiratory tract infections: Cluster-randomised, single-blinded intervention trial. Lancet 2004;363:600-7.
30. Rothenburger M, Markewitz A, Lenz T, Kaulbach HG, Marohl K, Kuhlmann WD, et al. Detection of acute phase response and infection. The role of procalcitonin and C-reactive protein. Clin Chem Lab Med 1999;37:275-9.

31. Ammori BJ, Becker KL, Kite P, Nylen ES, White JC, Barclay GR et al. Calcitonin precursors: Early markers of gut barrier dysfunction in patients with acute pancreatitis. Pancreas 2003;27:239-43.

32. Sato H, Sakai T, Sugaya T, Otaki Y, Aoki K, Ishii K, et al. Tocilizumab dramatically ameliorated life-threatening diarrhea due to secondary amyloidosis associated with rheumatoid arthritis. Clin Rheumatol 2009;28:1113-6.

33. Desideri-Vaillant C, Rouby Y, Cardon N, Vinsonneau U, Laborde JP. Analytical interference in determination of procalcitonin by PCT-Q (Brahms). Pathol Biol 2006;54:293-5.

34. Desvignes P, Boutib A. Semiquantitative determination of blood procalcitonin by the immunochromatographic BRAHMS PCT-Q test: False positive result. Ann Biol Clin 2005;63:358-9. 